Article available at http://www.parasite-journal.org or http://dx.dol.org/10.1051/parasite/200108s2117

\title{
A COMPARISON OF ANTIGENIC PEPTIDES IN MUSCLE LARVAE OF SEVERAL TRICHINELLA SPECIES BY TWO-DIMENSIONAL WESTERN-BLOT ANALYSIS WITH MONOCLONAL ANTIBODIES
}

\author{
DEA-AYUELA M.A. ${ }^{*}$, UBEIRA F.M..**, PITARCH A.**, GIL C.**, MARTÍNEZ-FERNÁNDEZ A.R.** \& BOLÁS F.*
}

\begin{abstract}
Summary :
The antigens recognised by mAb US5 specific to $53 \mathrm{kDa}$ glycoprotein (gp 53) in T. spiralis L-1 muscle larvae (TSL 1 ) antigens, mAb US9 specific to gp 53 in TSL 1 from all encapsulated species and mAb US4 specific to a tyvelose containing tetrasaccharide present in TSL I, were investigated in crude extracts from muscle larvae of $T$. spiralis, $T$. nativa and $T$. britovi by 2D-electrophoresis and western-blot. At least four proteins of different $p^{I}$ were recognised by mAb US5 on T. spiralis antigens. Recognition profile of mAb US9 on $T$. spiralis antigens exhibited some variation with regard to that of the US5.

Polymorphism was apparent in gp 53. High reactivity was shown by the mAb US4 with the three species.
\end{abstract}

KEY WORDS : Trichinella, 2-D electrophoresis, antigens.

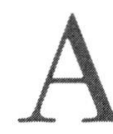

precise identification of Trichinella antigens is needed in order to select the most appropriate candidates for vaccination and immunodiagnosis strategies as well as to know their biological functions. Antigens from different stages of Trichinella species have been classically characterised by mono-dimensional electrophoresis followed by Western-blot and immunocytochemical techniques using defined monoclonal antibodies (Ortega Pierres et al., 1996, Boireau et al., 1997).

In proteomic studies high resolution systems are required for a quick protein separation and identification. Two-dimensional (2-D) electrophoresis is currently the single most powerful technique for analysis of complex mixtures of proteins and peptides.

In this work antigens in crude extracts from muscle larvae of T. spiralis, T. britovi and T. nativa were analysed using 2-D electrophoresis followed by Westernblot with three defined monoclonal antibodies.

\footnotetext{
* Departamento de Parasitología,

** Departamento de Microbiología II,

Facultad de Farmacia, Universidad Complutense, 28040-Madrid, Spain.

*** Departamento de Microbiología y Parasitología, Facultad de Farmacia, Universidad de Santiago, 15706, Santiago de Compostela, Spain.

Correspondence: F. Bolas

Tel.: 34-91 3941818 - Fax: 34-91-394 1815.

E-mail: bolas@eucmax.sim.ucm.es
}

MATERIAL AND METHODS

\section{PARASITES}

1 The following Trichinella isolates were used: T. spiralis (MFEL/SP/63/ISS48), T. britovi (MCAN/SP/ 76/ISS11) and T. nativa (MPAN/SU/87/ISS71). They are maintained under laboratory conditions by periodical passage in Swiss-CD1 mice. The methods for infection and larval recovery were those described by Denham \& Martínez, (1970).

\section{PREPARATION OF CRUDE LARVAL EXTRACT}

Muscle larvae crude extract (MLCSE) from the three Trichinella isolates were prepared following the method described by Lee et al., (1982).

\section{MONOCLONAL ANTIBODIES}

Three monoclonal antibodies (mAbs) named US4, US5, US9 were selected from a panel of mAbs raised by immunodefficient immunising mice expressing the Xidgene with TSL1 antigens (Ubeira F.M., unpublished). US5 mAb recognizes gp 53 TSL1 antigen present only in T. spiralis whereas US9 mAb recognizes gp 53 from all encapsulated species of Trichinella. US4 mAb recognises a tyvelose-containing tetrasaccharide within the TSL1 group of Trichinella antigens. All of them are of the IgG1k subclass (Romaris et al., personal communication).

\section{2-D ELECTROPHORESIS}

2-D electrophoresis was performed using an IPG system as described by Bjellqvist et al., (1993). Samples (aproximately $2 \mathrm{mg}$ of protein) were loaded onto rehydrated Immobiline Dry Strips (linear $\mathrm{pH}$ 47, $18 \mathrm{~cm}$ long, Pharmacia, Uppsala, Sweden) and run for the first dimension on a Multiphor II electrophoresis unit. After focusing, the second-dimensional run (SDS-PAGE) was carried out on homogeneous gels $(10 \%)$ in an Protean II unit (Bio-Rad). Analytical gels were silver stained according to Merril et al., (1982). 


\section{IMMUNOBLOT}

Following analytical 2-D PAGE, the gels were electroblotted onto nitrocellulose membranes according to standard protocols. MAs US4, US5 and US9 were used at 1: 10,000,1:4,000 and 1: 3,000 dilutions, respectively. Immunoreactive spots were detected using horseradish peroxidase-labelled anti-mouse $\operatorname{IgG}^{+} \mathrm{M}$ (Caltag) at 1:3000 dilution and an enhanced chemiluminiscence detection system (ECL Amersham, Sweden).

\section{RESULTS}

There were numerous protein spots in silver stained gels following separation of MLCSE from the three species. The spots ranged from 10 to above $90 \mathrm{kDa}$ and from four to seven $\mathrm{pI}$ with some variation among the three species. Antigens developed with specific polyclonal antibodies show about 90-100 spots with some apparent differences among species (data not shown). As expected, mAb US5 only reacted with MLCSE from T. spiralis showing at least four isoforms (pI around 6.0-6.7) of about $53 \mathrm{kDa}$ (Fig. 1A). The highest protein recognition capacity was shown by mAb US 4 with several isoforms ranging from pI 5.3 to 6.7 that varied in MW among the three species (data not shown). Recognition profiles of mAb US9 on T. spiralis and $T$. nativa were similar to those shown by mAb US5 with slight variation in MW and pI (Fig. 1B and $1 \mathrm{C}$, respectively). In T. britovi additional isoforms were observed at about $60 \mathrm{kDa}$ (Fig. 1D).

\section{DISCUSSION}

Whese results show that 2D-electrophoresis is a useful technique for a detailed analysis of Trichinella proteins and antigens. Proteinic and
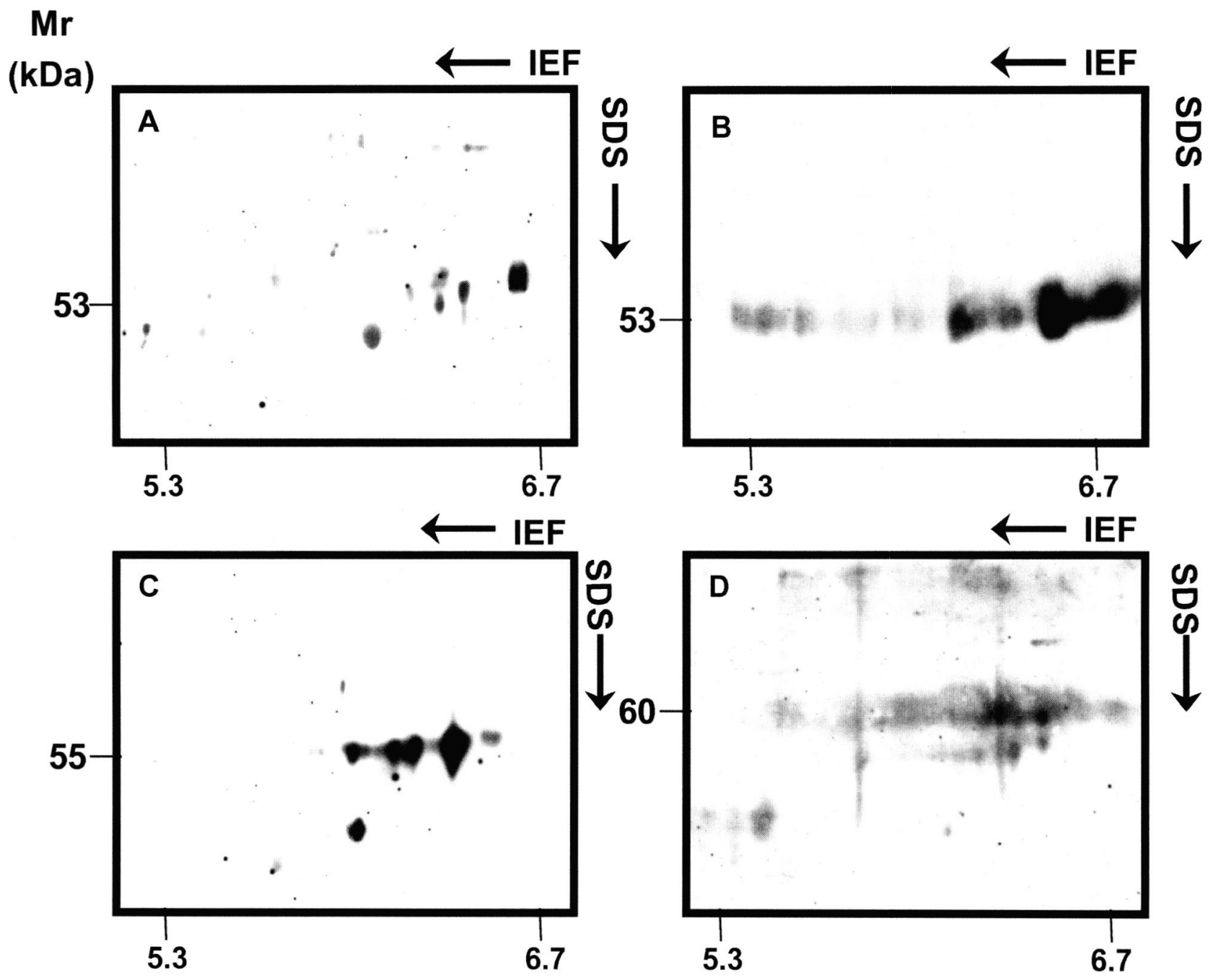

Fig. 1. - Western-blot analysis of mAb US5 with MLCSE of T. spiralis (A) and mAb US9 with MLCSE of T.spiralis (B), T. nativa (C) and T. britovi (D) after separation by 2-D electrophoresis. 
antigenic maps concerning $T$. spiralis using specific immune sera are similar to those previously reported (Wu et al.,1999) although the recognition patterns of mAbs varied due to the use of different probes. The restriction of the epitope recognised by mAb US5 to T. spiralis is confirmed; however, here it is shown that this epitope appear to be present in at least four protein isoforms. In addition, some variation was observed among the three species in proteins carrying the epitope recognised by mAb US9. By cloning and sequencing studies it was suggested that the proteins (gp 53) carrying the epitopes for mAbs US5 and US9 is the same in T. spiralis than in the other encapsulated species, respectively, although exhibiting different levels of glycosilation (Dr. Rodriguez et al., personal communication). This is quite consistent with our results and additionally, polymorphism for this protein is suggested by the presence of isoforms that vary among the three species. This polymorphism can be due to individual variation in expression of gp 53 by the Trichinella L1 larvae. The recognition profiles of mAb US4 reveals the high content of tyvelose caped tetrasaccharide in the three species with variation at both MW and $\mathrm{pI}$.

In summary our results indicate that this technology can be complementary to genomics in studying Trichinella antigens at the expression level.

\section{ACKNOWLEDGEMENTS}

This work was partially funded by project FIS $n^{\circ} 00 / 0778$.

\section{REFERENCES}

Bjellqvist B., Pasqualli C., Ravier F., Sanchez J.C.\& HochsTRASSER D.F. Electrophoresis, 1993, 14, 1357-1365.

Denham D. \& Martinez A.R.M. Studies with methyridine and Trichinella spiralis. II. The use of the drug to study the rate of larval production in mice. Journal of Helminthology, 1970, 44, 357-363.

LeE T.D.G., Grencis R.K. \& WaKelin D. Specific cross-immunity between Trichinella spiralis and Trichuris muris: immunization with heterologous infections and antigen transfer to immunity with heterologous immune mesenteric lymph node cells. Parasitology, 1982, 84, 381-389.

Merril C.R., Goldman D. \& Van Keuren M.L. Electrophoresis, 1982, 3, 17-21.

Ortega-Pierres G., Yepez-Mulia L., Homan W., Gamble H.R., LiM P.I., TAKAHASHI Y., WasSON D.L. \& APPLETON J.A. Workshop on a detailed characterization of Trichinella spiralis antigens: a plattform for future studies on antigens and antibodies to this parasite. Parasite Immunology, 1996, 18, 273-284.

Boireau P., Vayssier M., Fabien J.F., Perret C., Calamel M. \& Soulé C. Characterization of eleven antigenic groups in Tri- chinella genus and indentification of stage and species markers. Parasitology, 1997, 115, 641-651.

Wu Z., Nagano I. \& Takahashi Y. A panel of antigens of muscle larvae of Trichinella spiralis and T. pseudospiralis as revealed by Two-dimensional western blot and immunoelectron microscopy. Parasitology, 1999, 118, 615-622. 